\title{
Mistet en god venn, forbilde og storebror
}

Tekst og foto: Ingeborg Vea

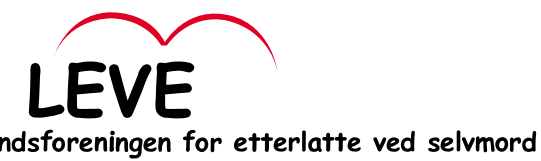

Marius Kampen Engevold mistet broren sin i selvmord da han var 19 år. Først 3 år senere fikk han hjelp som virkelig hjalp.

-Det å treffe andre på min egen alder som har opplevd det samme, har vært den beste hjelpen for meg. De kunne bekrefte at det var normalt å tenke som jeg gjorde om det som hadde skjedd. Det var veldig greit, sier Marius.

"De kunne bekrefte at det var normalt å ten ke som jeg gjorde"

Marius ble invitert til en helgesamling for ungdom i regi av Unge LEVE, ungdomsforeningen til Landsforeningen for etterlatte ved selvmord. $H$ an takket nølende ja.

-Det var helt forferdelig. Jeg hadde nettopp hatt muntlig eksamen, og ville mye heller drikke meg full sammen med de andre studentene enn å troppe opp alene på en helgesamling der jeg ikke kjente noen.

I etterkant er Mariusglad for at han dro. -Samlingen ble en opplevelse for meg. Jeg sa ikke mye, men kjente en trygghet i å vite at de andre der også hadde mistet noen.

\section{Ulykken}

Marius' bror $\varnothing$ ystein var den midterste av tre brødre. To og et halvt år før han tok livet sitt skjedde det fatale; under et fallskjermhopp løste fallskjermen seg ut for tidlig og viklet seg sammen med en annen fallskjerm. Livet til Øystein traff bakken med et smell. - H an landet med en fart på 50 kilometer i timen. Det tilsvarer et hopp fra 10-meteren rett i bakken. Ryggen hans ble kraftig sammentrykt og flere ryggvirvler ble knust. $\varnothing$ ystein ble lam i begge stortærne og mistet balansen slik at han fikk problemer med å gå. $M$ en det verste var smertene. For å holde ut tok han sterke smertestillende medikamenter, forteller Marius.

Fra å være i "livets vår" var Marius' gode venn, forbilde og storebror plutselig blitt en rekonvalesent. Etter ett halvt år på sykehus og påfølgende opptrening på Sunnås, ventet Øystein på å få operert inn en smertepumpe i ryggen.

-Smertepumpen var hans håp om å kunne leve et normalt liv. Den skulle gjøre andre smertestillende medikamenter unødvendig. $\mathrm{H}$ an skulle slippe å kjenne seg så sløv, og han håpet å få lappen tilbake.

På grunn av streik blant sykepleierne ble operasjonen utsatt. For $\varnothing$ ystein var det dråpen som fikk begeret til å flyte over;

-Det ble et triggerpunkt. Jeg hadde funnet $\varnothing y s t e i n$ i tide to ganger før da han hadde tatt en overdose piller. $\mathrm{H}$ an var langt nede. Kalte seg selv en "grønnsak". Denne gangen fant vi han for sent.

Marius hadde forsøkt å få han til å snakke. Uten hell.

-Vi hadde alltid hatt et nært forhold. Det var han som lærte meg å spille fotball, tok meg med på ting. $\mathrm{H}$ an lyttet veldig til det jeg sa, men ville ikke snakke om det som plaget han.

"Det var han som lærte meg å spille fotball, tok meg med på ting"

\section{Telefonen}

Telefonen kom midt på natta. Marius hadde akkurat kommet tilbake fra sin første perm på befal skolen .

-jeg hadde forsøkt å ringe $\varnothing$ ystein hele uka, men han tok ikke telefonen. Det var den andre broren min som fant han og som ringte meg. $\mathrm{H}$ an hadde til slutt fått politiet til å àpne leiligheten hans. Da var Øystein død.

$\mathrm{H}$ an etterlot seg et avskjedsbrev. $\mathrm{H}$ an var sint. Sint på familien, sint på helsevesenet.

-H an synes ikke de rundt hadde gjort nok for å hjelpe han. Før han døde, var jeg den eneste han hadde kontakt med i familien, sier Marius.

\section{"Kunne jeg ha forhindret det? H vorfor gjorde han det?"}

Etter begravelsen dro Marius rett tilbake til befalskolen. $\mathrm{H}$ an avfeide morens forsøk påå få han til å snakke med noen.

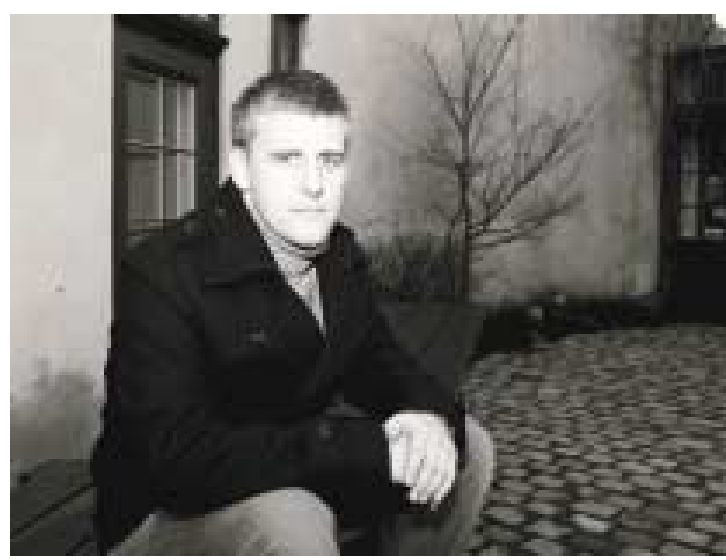

Ikke lett: -Det var ikke alltid lett å snakke om mine bekymringer med foreldrene mine. De hadde nok med si egen sorg, sier Marius Kampen Engevold (26)

-jeg tok meg ikke tid til det. Tilbake på befal skolen slet jeg med masse tanker; kunne jeg ha forhindret det? $\mathrm{H}$ vorfor gjorde han det? Jeg hadde problemer med å konsentrere meg, men klarte meg så vidt gjennom skoleåret.

\section{Ble voksen}

Brorens selvmord forandret Marius. -Det gjorde veldig mye med meg. Jeg ble brått voksen og begynte å sette pris på andre ting enn festing og tulling og slikt.

Kompisene til Marius trakk seg unna. De visste ikke hvordan de skulle forholde seg til han etter det som hadde skjedd.

-De droppet å ringe meg og besøkte meg ikke lenger. Jeg gjorde et forsøk på à være sammen med dem en kveld, men de visste ikke hva de skulle si til meg. Familien ble mye viktigere enn før. Kompiser kommer og går, men familien er der.

$N a ̊$ er det snart sju år siden Øystein døde. Marius har samboer, nye venner og et stort engasjement for andre unge som opplever å miste noen. $\mathrm{H}$ an er inne i sin andre periode som ungdomsrepresentant i Leves landsstyre, og jobber aktivt for å få U nge L eve opp og stå. -H vis jeg kan bidra til å hjelpe andre slik jeg fikk hjelp, hadde det vært fint, sier Marius. 